\title{
Analysis of baseline and cisplatin-inducible gene expression in Fanconi anemia cells using oligonucleotide-based microarrays Quinten Waisfisz ${ }^{1}$, Akira Miyazato ${ }^{2}$, Johan P de Winter ${ }^{1}$, Johnson M Liu ${ }^{2}$ and Hans Joenje*1
}

Address: ${ }^{1}$ Department of Clinical Genetics and Human Genetics, VU University Medical Center, Amsterdam, The Netherlands and ${ }^{2}$ The Hematology Branch, National Heart, Lung and Blood Institute, Bethesda, MD, USA

E-mail: Quinten Waisfisz - q.waisfisz.humgen@med.vu.nl; Akira Miyazato - amiya@jichi.ac.jp; Johan P de

Winter - j.de_winter.humgen@med.vu.nl; Johnson M Liu - Johnson.Liu@mssm.edu; Hans Joenje* - h.joenje.humgen@med.vu.nl

${ }^{*}$ Corresponding author

Published: 26 November 2002

BMC Blood Disorders 2002, 2:5

This article is available from: http://www.biomedcentral.com/I47I-2326/2/5

(C) 2002 Waisfisz et al; licensee BioMed Central Ltd. This is an Open Access article: verbatim copying and redistribution of this article are permitted in all media for any purpose, provided this notice is preserved along with the article's original URL.
Received: 3 October 2002

Accepted: 26 November 2002

\begin{abstract}
Background: Patients with Fanconi anemia (FA) suffer from multiple defects, most notably of the hematological compartment (bone marrow failure), and susceptibility to cancer. Cells from FA patients show increased spontaneous chromosomal damage, which is aggravated by exposure to low concentrations of DNA cross-linking agents such as mitomycin $C$ or cisplatin. Five of the identified FA proteins form a nuclear core complex. However, the molecular function of these proteins remains obscure.
\end{abstract}

Methods: Oligonucleotide microarrays were used to compare the expression of approximately 12,000 genes from FA cells with matched controls. Expression profiles were studied in lymphoblastoid cell lines derived from three different FA patients, one from the FA-A and two from the FA-C complementation groups. The isogenic control cell lines were obtained by either transfecting the cells with vectors expressing the complementing cDNAs or by using a spontaneous revertant cell line derived from the same patient. In addition, we analyzed expression profiles from two cell line couples at several time points after a I-hour pulse treatment with a discriminating dose of cisplatin.

Results: Analysis of the expression profiles showed differences in expression of a number of genes, many of which have unknown function or are difficult to relate to the FA defect. However, from a selected number of proteins involved in cell cycle regulation, DNA repair and chromatin structure, Western blot analysis showed that $\mathrm{p} 2$ | $\mathrm{waf}\left|/ C_{i p}\right|$ was significantly upregulated after low dose cisplatin treatment in FA cells specifically (as well as being expressed at elevated levels in untreated FA cells).

Conclusions: The observed increase in expression of $\mathrm{p} 2 \mid$ waf $|/ C i p|$ after treatment of FA cells with crosslinkers suggests that the sustained elevated levels of $\mathrm{p} 2$ |wafl/Cipl in untreated FA cells detected by Western blot analysis likely reflect increased spontaneous damage in these cells. 


\section{Background}

The autosomal recessive disorder Fanconi anemia (FA) is clinically characterized by bone marrow failure, predisposition to cancer and various developmental abnormalities [1]. FA is genetically heterogeneous, and thus far eight complementation groups have been described. Six of the identified FA genes (FANCA, $-C,-D 2,-E,-F$, and $-G$; [2-8]) encode proteins that are unique and lack apparent homology to other proteins or to each other. In addition, there are no conserved motifs present in these FA proteins, hampering understanding of their molecular function. Recently, biallelic mutations were found in the BRCA2 gene in patients belonging to complementation groups FA-D1 and one FA-B patient [9]. At the cellular level, FA is characterized by increased spontaneous genomic instability and hypersensitivity to DNA crosslinking agents, e.g. cisplatin and mitomycin C (MMC) [reviewed in [1]]. Multiple studies have also shown defects in FA cells related to the interferon-signaling pathway. Compared to control cells, FA cells express constitutively high levels of ISGF3 gamma, IRF-1, p21waf1/Cip1 and MxA $[10,11]$.

Studies on the FA proteins have shown that five FA proteins, FANCA, FANCC, FANCE, FANCF, and FANCG, bind to each other to form a nuclear core complex [Reviewed in [12] and [13]]. FANCD2 is a nuclear protein that requires activation by mono-ubiquitination. In mutant FA cells that lack one of the FA core complex proteins, FANCD2 is not activated by ubiquitination, suggesting that these FA proteins exert a common molecular function in the nuclear compartment of the cell [14]. Whether BRCA2 is involved in the same pathway or exerts a separate function is currently unknown [15].

Crosslinking agents are widely used for the treatment of various types of cancer and are thought to exert their cytotoxic effect predominantly through irreversible binding with DNA. How the FA proteins are related to this cytotoxic effect, e.g. by functioning in processes such as DNA repair, cell cycle control or protection, is unknown. Upon treatment with a discriminating dose of crosslinking agent that will only transiently arrest the growth of wild type cells, FA cells arrest in the late S or early G2-phase of the cell cycle, and ultimately undergo cell death [16-21]. In contrast to normal cells, FA cells fail to inhibit replicative DNA synthesis after treatment with crosslinking agents. While normal cells will arrest in S-phase, FA cells continue replication and subsequently arrest at a later cell cycle check point $[22,23]$. This hypersensitivity to crosslinking agents is the hallmark of the FA phenotype.

Many studies have indicated that in vitro treatment of cells with cisplatin affects the expression of specific genes involved in various molecular processes such as transcription, DNA repair, apoptosis, and cell cycle regulation.
Examples are induction of c-jun, c-fos, ercc1, gadd45, gadd153, and p21waf1/Cip1 [24-28]. Some of these genes respond within hours after treatment of cells, e.g. c-jun, whereas others show maximum changes in expression after 24 to 72 hours, e.g. p21waf1/Cip1, gadd45 and gadd 153.

Recently developed techniques, cDNA microarrays and oligonucleotide expression probe arrays, enable the systematic analysis of expression of thousands of genes in a single experiment [reviewed in [29]]. These techniques are useful to evaluate possible differences in gene expression profiles between FA and control cells, either at baseline or after crosslinker treatment. To study this, there are a number of experimental approaches to consider. For example, one might compare FA cells with cells from healthy controls. This might necessitate studying a large number of both types of cells in order to reduce false positives due to genetic differences in the cell lines that are unrelated to FA. Another approach would be to study cell lines derived from FA patients that are compared with the same cell lines corrected by transfection with the complementing cDNA. The use of such isogenic cell lines would presumably reduce the number of false positives and therefore reduce the number of cell lines that need to be studied. However, this might also result in a non-physiologic expression of the FA protein in transfected cells, which might influence the expression profiles. Therefore, we used the latter approach in combination with a unique cell line couple, one FA-like cell line and one wild-type, which are both derived from the same (mosaic) patient [30]. This cell line couple has the advantage of being both isogenic and expressing physiologic levels of the FA gene.

The aim of this study was to compare the expression profiles of FA cells defective in one of the FA core complex proteins with isogenic control cells at baseline, as well as in response to treatment with discriminating concentrations of crosslinking agents. Differences in expression profiles of known genes might shed light on the cellular function of the FA proteins.

\section{Methods \\ Cell lines and cell culture}

Lymphoblastoid cell lines that were used in this study are derived from three individuals, one FA-A (HSC72) and two FA-C (HSC536 and VU450) patients. The isogenic control cell lines included an in vivo revertant cell line derived from a mosaic patient, VU450R and the non-reverted cell line VU450, or were derived by transfecting the cells with either empty vector or with vectors expressing the complementing cDNAs, HSC72 with pDR2 or pDR2FANCA-flag [31] and HSC536 with pDR2 or pDR2-flagFANCC [17]. The VU450R cell line is an ideal isogenic control, since reversion by recombination resulted in endogenous wild-type FANCC expression [30]. Cells were 
cultured at $37^{\circ} \mathrm{C}$ in $5 \% \mathrm{CO}_{2}$ in RPMI1640 medium (Life Technologies, Gaithersburg, MD) containing 10\% newborn calf serum (Hyclone Laboratories, Lorgan, UT) and supplemented with $200 \mu \mathrm{g} / \mathrm{ml}$ hygromycin for transfected cells.

\section{Cisplatin treatment}

Optimal discriminating doses of cisplatin (Pharmachemie b.v., NL) for each cell couple were determined using growth inhibition tests [32,33]. Cells were pulse treated for 1 hour with different concentrations $(0,0.2,0.5,1,2$, $5,10,20$, and $50 \mu \mathrm{M}$ ) of cisplatin. Cells were subsequently washed and allowed to grow further until three cell divisions were reached in the untreated samples. For further analysis, concentration of cisplatin was such that the highest differential effect between the FA and control cells was obtained, i.e. growth inhibition of $>50 \%$ in FA cells and $<10 \%$ in control cells: for the VU450 cell couple, $2.5 \mu \mathrm{M}$; HSC536 cell couple, $1 \mu \mathrm{M}$; and HSC72 cell couple, $5 \mu \mathrm{M}$. Approximately $10^{8}$ cells were pulse treated with cisplatin for one hour, washed and cultured further in separate portions of $2.5 \times 10^{7}$ cells in fresh medium.

\section{RNA isolation}

Cells were harvested at various time points after treatment. Total RNA was extracted using TRIzol LS reagent (Life Technologies, Gaithersburg, MD) followed by a second round of RNA purification using RNAeasy columns (QIAGEN, Valencia, CA). Gene expression profiles were determined from the three cell couples without treatment, from the HSC72 cell couple 1, 3, 7 and 24 hours after cisplatin treatment, and from the VU450 cell couple 1 and 7 hours after treatment.

\section{Genechip expression analysis}

Gene expression profiles were determined using the Human Genome U95A probe arrays (Affymetrix, Santa Clara, $\mathrm{CA})$ according to the manufacturer's protocol. These genechips are oligonucleotide-based and represent $\sim 12,000$ human sequences that were previously characterized in terms of function or disease association. Double stranded cDNA was synthesized from each total RNA sample (10 $\mu \mathrm{g})$ using T7-(dT)24 primer (GENSET Corp) and SuperScript Choice system (Life Technologies, Rockville, MD). From these cDNA samples, target samples were prepared using in vitro cRNA transcription with biotinylated nucleoside triphosphates and BioArray High Yield RNA Transcript Labeling Kit (Enzo Diagnostics, Farmingdale, NY). The cRNA samples were fragmented and hybridized to U95A probe arrays. Scanning of the arrays was performed with the HP Gene Array Scanner and data quantified using Genechip Analysis Suite 3.3 (Affymetrix, Santa Clara, CA).

\section{Data analysis}

For analysis of the data, the data from all untreated cell couples were combined and used as baseline for normalization. All data sets were subsequently calculated relative to the normalized data. Expression levels of beta-actin and GAPDH (relative intensity) ranged between $0.8-1.2$ in all data sets. Genechip Analysis Suite 3.3 (Affymetrix, Santa Clara, CA) and GeneSpring 3.2.2 software (Silicon Genetics, Redwood, CA) was used for analysis of the data. A gene was considered as being up- or down-regulated only if the average difference (AD) was $>10$ (with target intensity for scaling $=100$ ) and if gene was called present. Genes considered of potential interest were: genes $>2$-fold up- or down-regulated in all pairs for non-treated samples when comparing FA $v$ control, and $>3$-fold up- or downregulated at any time point after cisplatin treatment in either cell couple. A further selection from the latter set of genes was made by scrutinizing for consistency in changes of expression among cell line couples and in response to cisplatin treatment (as indicated in table 2).

\section{Immunoblotting}

Protein extracts were prepared from cells as described previously [34]. Protein concentration in the extracts was determined using a Bio-Rad Protein Assay (Hercules, CA), and $10 \mu \mathrm{g}$ protein was loaded on SDS-polyacrylamide gels. Gels were transferred to Immobilon-P membrane (MILLIPORE, Bedford, MA) and blocked in TBST with either $5 \%$ dry milk or $5 \%$ BSA for 1 hour at room temperature. Incubation with primary antibody was according to the manufacturer's protocols. The following primary antibodies were used for immunoblotting: mouse anti-p300 (NM-11) and rabbit anti-p21waf1/Cip1 (Zymed Laboratories, San Francisco, CA), mouse anti-CDC25a (abcam, UK), mouse anti-PMS2 (E-19), rabbit anti-RGS2, rabbit anti-BAF170 (Santa Cruz Biotechnology, Santa Cruz, CA), mouse anti-p16 (G175-405; PharMingen), and mouse anti- $\beta$-tubulin (Boehringer Mannheim).

\section{Results}

\section{Expression analysis of untreated cells}

Expression data from three different cell line couples, FA cell lines (HSC72, HS536, and VU450) and their isogenic controls (HSC72 + FANCA, HSC536 + FANCC, and VU450 revertant), were analyzed. In addition, for two cell line couples (HSC72 and VU450), expression profiles were determined after treatment with discriminating concentrations of cisplatin. In general, approximately half of the genes present on the probe arrays were identified as being expressed in the lymphoblastoid cell lines. Some low abundant mRNAs were not detected, as evidenced by the fact that of the four FA genes present on the arrays (FANCA, FANCC, FANCD2 and FANCG), only one (FANCG) was detected, in both FA and control cell lines. 
Table I: Differentially expressed genes in untreated FA cells.

\begin{tabular}{|c|c|c|c|c|}
\hline Description & GenBank accession no. & & Fold change & \\
\hline Up regulated in FA cells & & VU450 & HSC536 & HSC72 \\
\hline - GLUTI C-terminal binding protein, GIPC & AF089816 & 5 & 2 & 17 \\
\hline - homeo box B7, HOXB7 & MI6937 & 5 & 61 & 3 \\
\hline - plasma glutamate carboxypeptidase, PGCP & W29330 & 5 & 3 & 2 \\
\hline - proteinase inhibitor, SERPINB7 & U7I364 & 7 & 2 & 6 \\
\hline - EIA binding protein p300, EP300 & U0।877 & 2 & 2 & 2 \\
\hline \multicolumn{5}{|l|}{ Down regulated in FA cells } \\
\hline - selectin L, SELL & $M 25280$ & 2 & 16 & 5 \\
\hline - small inducible cytokine A4, SCYA4 & J04130 & 2 & 3 & 41 \\
\hline - TXK tyrosine kinase, TXK & L2707। & 10 & 3 & 3 \\
\hline - solute carrier family $16, \mathrm{SCLI} 6 \mathrm{~A} 5$ & U59299 & 2 & 2 & 2 \\
\hline - cyclin-dependent kinase inhibitor 2A, pl6 & U26727 & 2 & 203 & 5 \\
\hline
\end{tabular}

As shown in Table 1, comparison of the expression profiles from the three FA cell lines and their isogenic controls showed that 10 genes were identified as being more than 2 -fold differentially expressed in all cell couples. Although we can not exclude that some of these genes may have a physiological effect, many of the genes in Table 1 are difficult to relate to the molecular defect in FA cells, i.e. genomic instability and cross linker sensitivity. There is still a reasonable chance that the majority of these genes were obtained by chance since only three cell line couples were used. Therefore, we further analyzed those most likely to be related to the FA phenotype, i.e. p300 and p16 that are involved in cell cycle regulation. However, comparison of protein expression by Western blotting showed no consistent differences in either p16 or p300 protein levels (Figure 1).

\section{Expression analysis of cisplatin-treated cells}

To test the possibility that the hypersensitivity of FA cells to crosslinking agents is reflected by a differential response at the level of gene expression, we first determined the concentration of cisplatin that best discriminated between the FA and control cell line couples. These concentrations were $2.5 \mu \mathrm{M}$ and $5 \mu \mathrm{M}$ cisplatin for the VU450 and HSC72 cell couples, respectively (Figure 2 and data not shown).

Using specific criteria for differences in response (see methods section), analysis of the expression profiles from untreated versus 1 and 7 hours after cisplatin treatment for the VU450 cell couple and from untreated versus 1, 3, 7 , and 24 hours after treatment for the HSC72 cell couple, resulted in 59 genes that were initially identified (Table 2). The selection criteria were mild, in order to avoid loss of interesting data, thus increasing the risk of identifying

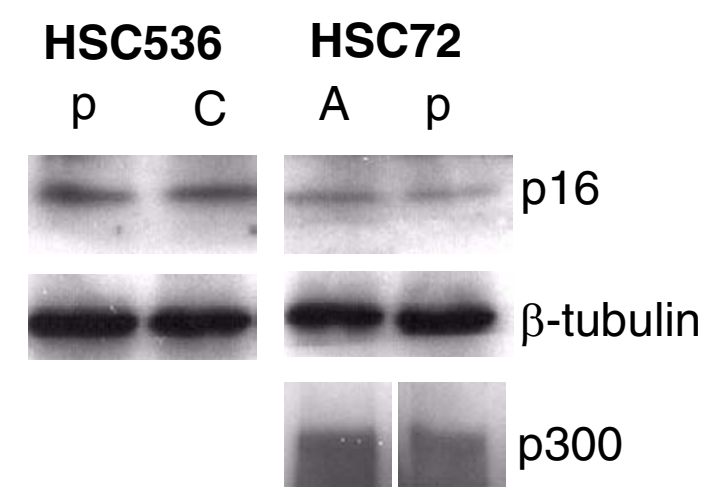

Figure I

p 16 and p300 protein expression in FA and control cell lysates. $10 \mu \mathrm{g}$ protein from indicated cell extracts were immunoblotted with pl6, $\beta$-tubulin, and p300 specific antibodies, as indicated. Extracts were from HSC536 stably transfected with empty vector ( $p$; lanes I) or with vector expressing FANCC (C; lanes 2), and from HSC72 stably transfected with vector expressing FANCA (A; lanes 3$)$ or with empty vector ( $p$; lanes 4$)$. $\beta$-tubulin was used as additional loading control.

genes by chance. This is reflected by the facts that many genes do not show a clear pattern of response to cisplatin treatment and that all genes are in the low intensity range. However, some of the genes in Table 2 are of possible interest in the context of FA and crosslinker treatment, particularly those involved in cell cycle regulation (cdc25A and RGS2), DNA repair (PMS2), and chromatin structure (BAF170). Unfortunately, protein expression analysis us- 
Table 2: Differentially expressed genes between FA and control cells after cisplatin treatment.

\begin{tabular}{|c|c|c|}
\hline Gene Description & GenBank accession no. & Change* \\
\hline \multicolumn{3}{|l|}{ Membrane protein } \\
\hline C-type lectin, AICL & $\times 96719$ & Up I h in WT \\
\hline Integral membrane protein, LIG-I & W25875 & Up I $h$ in FA \\
\hline Integral membrane protein, SIGMARI & U79528 & $\mathrm{NC}$ \\
\hline \multicolumn{3}{|l|}{ Growth factor } \\
\hline Insulin growth factor binding protein 2, IGFBP-2 & S37730 & NC \\
\hline Endothelial cell growth factor, platelet-derived, ECGFI & M63193 & Down $24 \mathrm{~h}$ in WT \\
\hline ILI8RI/IL-IRRP & U43672 & NC \\
\hline BMP-4 & U43842 & Down I h in FA \\
\hline ILIOR & U00672 & NC \\
\hline Notch ligand, JAGLI & AF003837 & NC \\
\hline \multicolumn{3}{|l|}{ Signal transduction } \\
\hline Adapter molecule in signal transduction, $\mathrm{DOCI}$ & U53445 & Up $24 \mathrm{~h}$ in FA \\
\hline SRC family tyrosine kinase, FYN & MI4333 & Down $24 \mathrm{~h}$ in FA \\
\hline Protein tyrosine phosphatase, PTPG & U46II6 & Down $>7 \mathrm{~h}$ in $\mathrm{FA}$ \\
\hline Regulator of G-protein signaling, G0S8/RGS & LI3463 & Up I h in FA \\
\hline Regulator of G-protein signaling, GIPC/RGSI9IPI & AF089816 & Up $24 \mathrm{~h}$ in WT \\
\hline Mitogen-activated protein kinase kinase kinase kinase 4, MAP4K4 & $\mathrm{AB} 014587$ & NC \\
\hline Serine/threonine kinase, KIAA0623 & $\mathrm{AB} 014523$ & NC \\
\hline Related to the $\mathrm{N}$-terminus of TRE, RNTRE & DI3644 & NC \\
\hline Related to intracellular calcium signaling, HOMER-IB & YI7829 & NC \\
\hline MEK6/MKK6 & U39657 & NC \\
\hline Zinc finger protein, LOC58500 & $\times 16282$ & NC \\
\hline LYTIO/NF-kB2 & U20816 & NC \\
\hline Dual specific tyrosine kinase, DYRK2 & YI3493 & NC \\
\hline Phospholipase C beta 2, PLCB2 & M95678 & $\mathrm{NC}$ \\
\hline Containing Pleckstrin homology domain, KIAA0763 & $A B 18306$ & NC \\
\hline Vesicular Rab-GAP/TBC-containing protein, AD3 & AB024057 & NC \\
\hline Calcium-binding protein, S100C/Calgizzarin & D38583 & NC \\
\hline \multicolumn{3}{|l|}{ Transcription factor } \\
\hline Transcript homolog, MEST/PEGI & D786 II & NC \\
\hline Myotubularin related protein 2, MTMR2 & AB028996 & NC \\
\hline Homeobox protein related to skeletal development, MSXI & M97676 & NC \\
\hline Transcription factor, MRGI & U65093 & NC \\
\hline Homeobox, PRH/PRHX & LI6499 & NC \\
\hline MSX2/MSH/HOX8 & D89377 & NC \\
\hline Transcriptin activating factor, CREBP & L055I5 & NC \\
\hline Transcription coactivator, TCFEC/TFECL & D43945 & NC \\
\hline Putative transcription regulator, CARM-I & Al660225 & Down $7 \mathrm{~h}$ in $\mathrm{FA}$ \\
\hline \multicolumn{3}{|l|}{ Cell cycle } \\
\hline CDC25A & M81933 & NC \\
\hline \multicolumn{3}{|l|}{ Apoptosis } \\
\hline Similar to rat CIPHAR-I, DKFZp56400823 & AL080I2I & NC \\
\hline $\mathrm{BCLX}$ & Z23II5 & NC \\
\hline Protease inhibitor, PLANH2/PAI2 & Y00630 & $\mathrm{NC}$ \\
\hline Vanin-2, VNN2 & D89974 & Down $24 \mathrm{~h}$ in WT \\
\hline \multicolumn{3}{|l|}{ DNA repair/Chromosome regulator } \\
\hline Similar to DNA helicase, FLJ10738 & W28620 & $\mathrm{NC}$ \\
\hline HPARG & AF005043 & NC \\
\hline BAFI70 & U66616 & NC \\
\hline PMS2 & U13696 & NC \\
\hline \multicolumn{3}{|l|}{ Intracellular processing } \\
\hline Ubiquitin protein ligase, E6-AP & AF002224 & $U_{p}>I$ h in WT \\
\hline Putative splicing factor, DOM $3 Z$ & AF059252 & Down $>7 \mathrm{~h}$ in FA \\
\hline CBP2/TAFI & M75I 06 & NC \\
\hline Uronyl 2-sufotransferase & AB020316 & NC \\
\hline \multicolumn{3}{|l|}{ Miscellaneous } \\
\hline Procollagen-proline, 2-oxoglutarate 4-dioxygenase, P4HA2 & U9044I & NC \\
\hline
\end{tabular}


Table 2: Differentially expressed genes between FA and control cells after cisplatin treatment. (Continued)

\begin{tabular}{lll}
\hline Unknown, FLJ2II74 & AAI49307 & NC \\
Unknown, expressed in macrophage & X89059 & Up >I h FA \\
Clathrin light chain b & X81637 & NC \\
Related to lipodystrophy, LPIN2 & D87436 & NC \\
MEI & U43944 & NC \\
Unknown, KIAA0090 & D42044 & Down 24h in WT \\
Unknown, DKFZp564II22 & AL080062 & NC \\
Unknown, KIAA024I & D887682 & NC
\end{tabular}

* NC indicates that the observed changes were not consistent. When consistent changes were observed indicated are up or down regulation, followed by time point(s) after treatment at which changes of expression were observed, and cell type; WT indicates observed in corrected cells, FA indicates observed in FA cells.

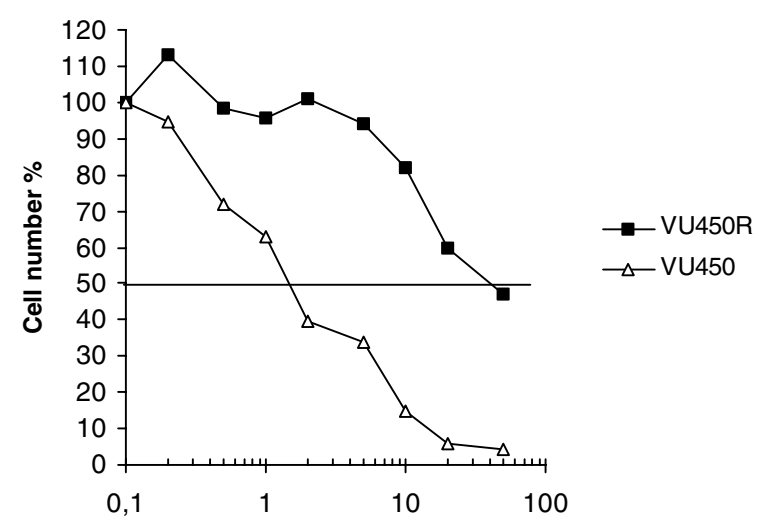

Figure 2

Cisplatin induced growth inhibition. VU450 cell lines were one hour pulse treated with indicated concentrations of cisplatin. Dotted line indicates the dosage used for gene expression experiments. VU450R; reverted (crosslinker resistant) cell line and VU450; FA (crosslinker sensitive) cell line.

ing Western blotting did not confirm any consistent changes in protein expression after cisplatin treatment (Figure 3A).

Of the genes with relatively high signal intensities, the cell cycle inhibitor p21waf1/Cip1 was increased in FA cells (HSC72) 24 hours after treatment but not in control cells (HSC72 + FANCA). However, this increase was $<2$-fold and therefore excluded in the initial analysis. Western blot analysis of $\mathrm{p} 21^{\text {waf1/Cip } 1}$ protein expression showed a strong increase in FA cells at 24 hours after cisplatin treatment, while p $21^{\text {waf } 1 / C i p 1}$ was only slightly increased in the corrected cells (Figure 3B). In addition, p21waf1/Cip1 appeared to be somewhat higher expressed in FA cells even without treatment, which was not observed in the expression array analysis.

\section{Discussion}

The FA proteins have a caretaker function and a defective FA pathway results in chromosomal instability, a phenotype that is aggravated by exposure of cells to cross-linking agents [1]. Here we have tried to identify differences in gene expression between FA and control cells that might shed light on the molecular role of the FA proteins. Although recent findings of BRCA2 mutations in a subset of FA patients and studies on the FANCD2 protein suggests a link between the FA pathway, BRCA1, and DNA repair $[9,14]$, the exact function of the FA core complex remains elusive.

We examined samples using oligonucleotide arrays harboring probes directed to approximately 12,000 different transcripts. Various types of crosslinking agents are used in FA research, such as mitomycin C, diepoxybutane, psoralen with $U V$, and cisplatin [1]. In the present study, we used cisplatin because the effect of this agent on gene expression has been well described and there is no need for metabolic activation of the drug (unlike mitomycin C). Relatively late effects, such as cell cycle arrest and apoptosis, have been documented for FA [16-23]. Our main interest, however, was to determine the effect on early response genes that preceded cell cycle arrest. Therefore, cells were pulse treated for one hour with cisplatin and samples taken shortly thereafter. The concentration of cisplatin used was chosen to achieve the highest discrimination between FA and control cells in growth inhibition assays. Although this cytotoxic dosage is relatively low compared to those used in prior studies of cisplatin-induced gene expression changes, we reasoned that a higher dosage would lead to indiscriminate growth inhibition in both FA and control cells $[17,18,20]$. In addition, these concentrations were found to be sufficient for inactivating tyrosine phosphorylation of CDC2, 24 hours post treatment, as assessed by Western blotting (data not shown).

The profiling analysis revealed differences in expression of a number of genes, many of which are difficult to relate to 

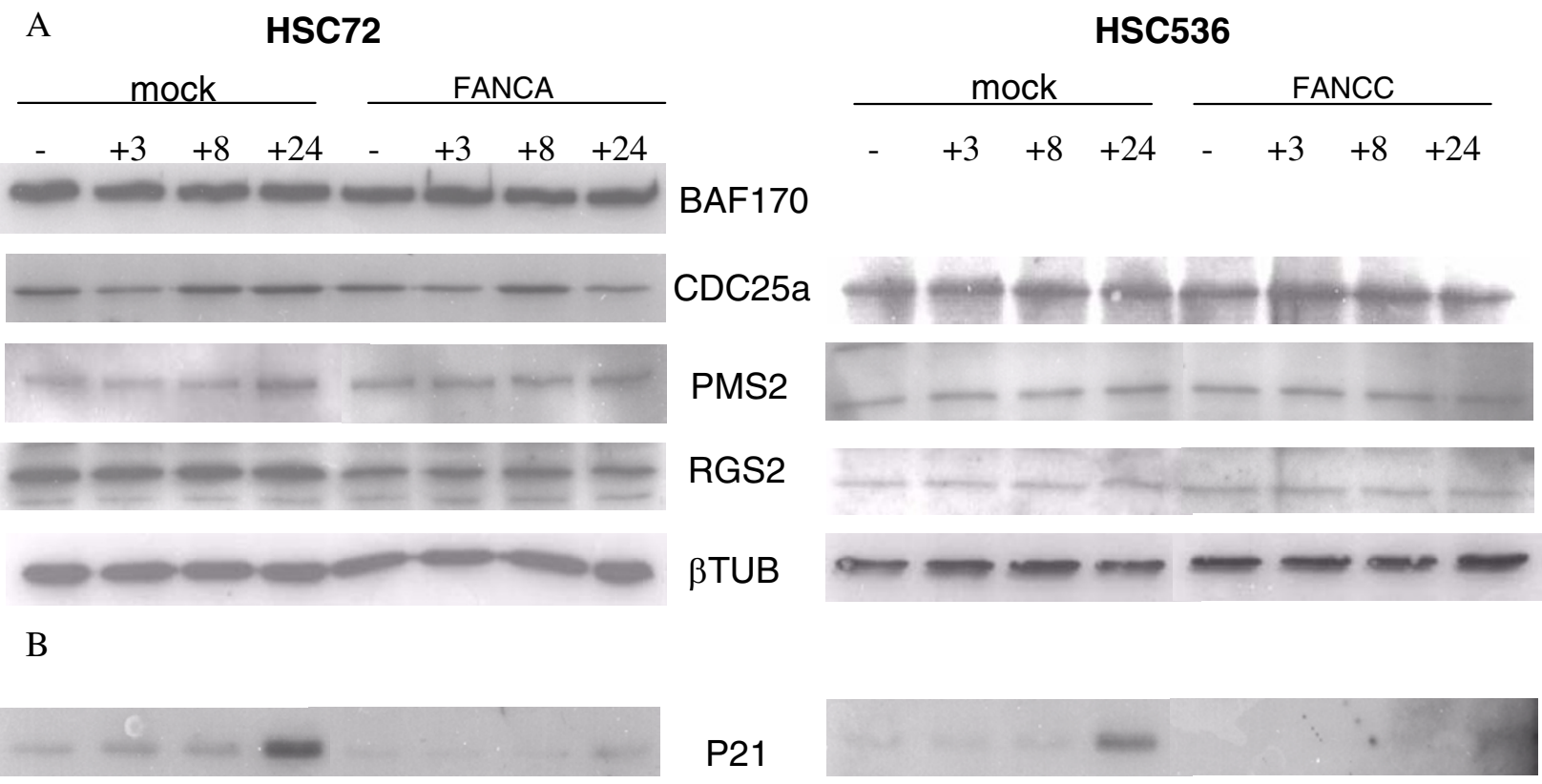

P21

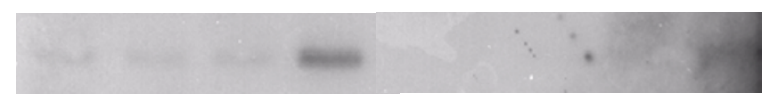

Figure 3

Protein expression in FA and control cells treated with cisplatin. $10 \mu \mathrm{g}$ protein from indicated cell extracts were immunoblotted with specific antibodies directed against indicated proteins; A) BAFI70, CDC25a, PMS2, RGS2 and $\beta$-tubulin; B) p2 I wafl/Cipl. Extracts were from HSC72 and HSC536 cells transfected with empty vector or with vector expressing correcting cDNA as indicated. Cells were one hour pulse treated with discriminating concentrations of cisplatin; HSC72 with $5 \mu$ M and HSC536 with I $\mu$ M. $\beta$-tubulin was used as additional loading control.

the FA pathway or are unlikely to be expressed in B-lymphocytes. Only a few genes are related to processes that are possibly linked to the FA defect, such as those involved in cell cycle regulation, chromatin structure, and DNA mismatch repair. However, using Western blot analysis with antibodies directed to the respective gene products, we were unable to confirm differences in protein levels for all these genes. Genes that previously have been shown to respond to cisplatin and that were present on the arrays, i.e. c-jun, c-fos, ercc1, gadd153, gadd45, pcna and p21waf1/ Cip1, were not changed under the conditions used, except for an increase in expression of $\mathrm{p} 21$ waf $1 /$ Cip 1 . Although the change in our experiments was $<2$-fold, there was a clear induction of $\mathrm{p} 21^{\text {waf } 1 / C i p 1}$ expression in FA cells 24 hours post treatment that was not seen in the control cells. Microarray based experiments to discover cisplatin induced differences in gene expression have been performed previously both using cell lines [35] and tissues from rats [36]. These experiments are however difficult to relate to our experiment due to much longer exposure time to similar concentrations of cisplatin used [35] or due to the differences in experimental approach [36]. Although in those experiments many genes were found to be differentially expressed, also p $21^{\text {waf } 1 / C i p 1}$ was found to be induced by cisplatin treatment. The reason for not detecting other cisplatin-induced genes in our experiments might be the relatively low concentrations of cisplatin used. This suggests that $\mathrm{p} 21^{\text {waf1/Cip } 1}$ (compared to other genes) regulation is very sensitive to cisplatin, at least in lymphoblastoid FA cells. p21 waf1/Cip1 is known to be a key regulator of $\mathrm{G} 1$ cell cycle arrest, but has more recently also been implicated in G2 cell cycle regulation [37]. This observation fits well with the previously observed upregulation of p53 and cyclin B proteins, inactivation of CDC2, and cell cycle arrest that follows exposure to low doses of cross-linking agents [17-19].

Earlier studies reported that FA lymphoblasts express increased levels of transcripts from genes connected to the interferon pathway, IRF-1 and MxA [10,11]. Although the approaches used were different, these observations are not confirmed by our data. Both genes were detected as being expressed but showed no significant differences between FA and controls. In addition, the constitutive elevated expression of $\mathrm{p} 21^{\text {waf } 1 / \text { Cip } 1}$ observed in FA cells [9] was not found at the level of mRNA in our experiments. However, we did observe a slight increased expression of p21waf1/ ${ }^{C i p 1}$ protein in FA cells. This might be explained by post- 
transcriptional regulation of $\mathrm{p} 21^{\text {waf } 1 / C i p 1}$ or by a relatively low sensitivity of the expression arrays, incapable of detecting minor increases in mRNA. Interestingly, the observed elevated levels of $\mathrm{p} 21^{\text {waf1/Cip } 1}$ expression in FA cells is reminiscent of a number of other DNA repair defective cell types, i.e. those defective in ATM, ERCC1, BRCA1, and BRCA2 [38-42].

Except for p21waf1/Cip1, these experiments did not reveal differences in gene expression that could explain the basic defect in FA, when looking at baseline or when looking for genes that preceded cisplatin-induced cell cycle changes. There are several possible explanations possible for this. First, no significant changes at the transcriptional level are present in FA cells. It might well be that phenotypic differences of FA cells are predominantly reflected at the posttranslational level. The recent finding of FANCD2 monoubiquitination suggests that regulation by protein modification is an important step in the FA pathway [14]. Second, subtle changes in gene expression might remain undetected. The up- or down-regulation of an entire functional pathway may have large effects but be difficult to trace using these types of experiments, particularly when our knowledge of components involved in the various functional pathways is limited. Third, expression of certain genes may be different but not detected either because of lack of sensitivity or absence of the oligonucleotide sequence for those specific genes in the arrays used. Concerning sensitivity, it might be that the response of cells to cross-linker damage is related to signals at a certain stage of the cell cycle (e.g. during replication), resulting in a dilution of the response when using an asynchronous population of cells. The p21waf1/Cip1 results showed that differences in expression of transcripts with high intensity on the arrays were detected even though this was a single data point and the difference was $<2$ fold. Therefore, differences $<2$-fold in genes with low intensity signals are presumably present but missed because of the increasing levels of noise in that region of intensity, making it difficult to discriminate between true and false positives in a limited number of samples.

\section{Conclusions}

Analysis of the expression data resulted in the identification of 10 genes (Table 1) that were found to be consistently differentially expressed between FA and control cells, as well as 59 genes (Table 2) that exhibited different response patterns between FA and control cells after treatment with cisplatin. However, subsequent analysis of selected genes at the protein level by Western blot analysis did not confirm the observed differences in expression. Several limitations of the experimental approach were discussed that might explain these results.
The observed strong cisplatin-induction of $\mathrm{p} 21^{\text {waf } 1 / \text { Cip } 1}$ in FA cells, but not in control cells, suggests that FA cells respond similarly as non-FA cells but in a hypersensitive manner. According to experiments from other investigators [20] cell cycle checkpoints function properly, suggesting that cross-linking agents evoke more damage or create damage that remains unrepaired in cells with a defective FA pathway. Therefore, the observed increase in basal p21 waf1/Cip 1 levels in FA cells by Western blot analysis most likely reflects a physiologic response to the presence of spontaneous damage in a subpopulation of these cells.

\section{Competing interests}

None declared.

\section{Authors' contributions}

QW and JdW performed all experiments, isolated, purified RNA from the samples for microarray, performed initial analysis and Western blotting. AM analysed the microarray data in further detail. $\mathrm{HJ}$ and JL participated in its design and co-ordination.

\section{Acknowledgements}

We thank J den Dunnen, J Boer and E Mank from the Leiden Genome Technology Center for technical support. Financial support was from NWO (90I-0I-190).

\section{References}

I. Auerbach AD, Buchwald M, Joenje H: Fanconi Anemia. In: The Genetic Basis of Human Cancer (Edited by: Vogelstein B, Kinzler KW) New York, McGraw-Hill 1998, 317-332

2. Strathdee CA, Gavish H, Shannon WR, Buchwald M: Cloning of cDNAs for Fanconi's anaemia by functional complementation. Nature 1992, 356:763-767

3. The Fanconi anaemia/breast cancer consortium: Positional cloning of the Fanconi anaemia group A gene. Nat Genet 1996, I4:324328

4. Lo ten Foe JR, Rooimans MA, Bosnoyan-Collins L, Alon N, Wijker M, Parker L, Lightfoot J, Carreau M, Callen DF, Savoia A, et al: Expression cloning of a CDNA for the major Fanconi anaemia gene, FAA. Nat Genet 1996, I 4:320-323

5. de Winter JP, Waisfisz Q, Rooimans MA, van Berkel CG, BosnoyanCollins L, Alon N, Carreau M, Bender O, Demuth I, Schindler D, et al: The Fanconi anaemia group G gene FANCG is identical with XRCC9. Nat Genet 1998, 20:281-283

6. de Winter JP, Rooimans MA, van Der Weel L, van Berkel CG, Alon N, Bosnoyan-Collins L, de Groot J, Zhi Y, Waisfisz Q, Pronk JC, et al: The Fanconi anaemia gene FANCF encodes a novel protein with homology to ROM. Nat Genet 2000, 24: I5-I6

7. de Winter JP, Leveille F, van Berkel CG, Rooimans MA, van Der Weel L, Steltenpool J, Demuth I, Morgan NV, Alon N, Bosnoyan-Collins L, et al: Isolation of a cDNA representing the Fanconi anemia complementation group E gene. Am J Hum Genet 2000, 67: I 3061308

8. Timmers C, Taniguchi T, Hejna J, Reifsteck C, Lucas L, Bruun D, Thayer M, Cox B, Olson S, D'Andrea AD, et al: Positional cloning of a novel Fanconi anemia gene, FANCD2. Mol Cell 200I, 7:24l-248

9. Howlett NG, Taniguchi T, Olson S, Cox B, Waisfisz Q, De DieSmulders C, Persky N, Grompe M, Joenje H, Pals G, et al: Biallelic inactivation of BRCA2 in Fanconi anemia. Science 2002, 297:606-609

10. Fagerlie SR, Diaz J, Christianson TA, McCartan K, Keeble W, Faulkner GR, Bagby GC: Functional correction of FA-C cells with FAN$C C$ suppresses the expression of interferon gamma-inducible genes. Blood 2001, 97:3017-3024 
II. Li Y, Youssoufian H: MxA overexpression reveals a common genetic link in four Fanconi anemia complementation groups. J Clin Invest 1997, I 00:2873-2880

I2. Joenje $\mathrm{H}$, Patel $\mathrm{KJ}$ : The emerging genetic and molecular basis of Fanconi anaemia. Nat Rev Genet 200I, 2:446-457

13. Grompe M, D'Andrea A: Fanconi anemia and DNA repair. Hum Mol Genet 200I, I 0:2253-2259

14. Garcia-Higuera I, Taniguchi T, Ganesan S, Meyn MS, Timmers C, Hejna J, Grompe M, D'Andrea AD: Interaction of the Fanconi anemia proteins and BRCAI in a common pathway. Mol Cell 200I, 7:249-262

15. Zdzienicka MZ, Arwert F: Breast cancer and Fanconi anemia: what are the connections? Trends Mol Med 2002, 8:458-460

16. Latt SA, Kaiser TN, Lojewski A, Dougherty C, Juergens L, Brefach S, Sahar E, Gustashaw K, Schreck RR, Powers M, et al: Cytogenetic and flow cytometric studies of cells from patients with Fanconi's anemia. Cytogenet Cell Genet 1982, 33: I33-138

17. Kruyt FA, Dijkmans LM, van den Berg TK, Joenje H: Fanconi anemia genes act to suppress a cross-linker-inducible p53-independent apoptosis pathway in lymphoblastoid cell lines. Blood 1996, 87:938-948

18. Kruyt FA, Dijkmans LM, Arwert F, Joenje H: Involvement of the Fanconi's anemia protein $F A C$ in a pathway that signals to the cyclin B/cdc2 kinase. Cancer Res 1997, 57:2244-225 I

19. Kupfer GM, D'Andrea AD: The effect of the Fanconi anemia polypeptide, FAC, upon p53 induction and G2 checkpoint regulation. Blood 1996, 88:1019-1025

20. Heinrich MC, Hoatlin ME, Zigler AJ, Silvey KV, Bakke AC, Keeble WW, Zhi Y, Reifsteck CA, Grompe M, Brown MG, et al: DNA cross-linker-induced G2/M arrest in group C Fanconi anemia lymphoblasts reflects normal checkpoint function. Blood I998, 91:275-287

21. Akkari YM, Bateman RL, Reifsteck CA, D'Andrea AD, Olson SB, Grompe M: The 4N Cell Cycle Delay in Fanconi Anemia Reflects Growth Arrest in Late S Phase. Mol Genet Metab 200I, 74:403-4I 2

22. Sala-Trepat M, Rouillard D, Escarceller M, Laquerbe A, Moustacchi E, Papadopoulo D: Arrest of S-phase progression is impaired in Fanconi anemia cells. Exp Cell Res 2000, 260:208-2I 5

23. Centurion SA, Kuo HR, Lambert WC: Damage-resistant DNA synthesis in Fanconi anemia cells treated with a DNA crosslinking agent. Exp Cell Res 2000, 260:216-221

24. Zhao R, Rabo YB, Egyhazi S, Andersson A, Edgren MR, Linder S, Hansson J: Apoptosis and $c$-jun induction by cisplatin in a human melanoma cell line and a drug-resistant daughter cell line. Anticancer Drugs 1995, 6:657-668

25. Rabo YB, Shoshan MC, Linder S, Hansson J: Different mechanisms are responsible for c-jun mRNA induction by cisplatin and ultraviolet light. Int J Cancer 1996, 65:821-826

26. Ballester A, Perez C, Aller P, Mata F: Differentiation of U-937 promonocytic cells with mitomycin $C$ or cis-diamminedichloroplatinum II. Int J Cancer 1996, 65:791-795

27. Li Q, Gardner K, Zhang L, Tsang B, Bostick-Bruton F, Reed E: Cisplatin induction of ERCC-I mRNA expression in A2780/CP70 human ovarian cancer cells. J Biol Chem 1998, 273:23419-23425

28. Delmastro DA, Li J, Vaisman A, Solle M, Chaney SG: DNA damage inducible-gene expression following platinum treatment in human ovarian carcinoma cell lines. Cancer Chemother Pharmacol 1997, 39:245-253

29. Young RA: Biomedical discovery with DNA arrays. Cell 2000, 102:9-15

30. Lo Ten Foe JR, Kwee ML, Rooimans MA, Oostra AB, Veerman AJ, van Weel M, Pauli RM, Shahidi NT, Dokal I, Roberts I, et al: Somatic mosaicism in Fanconi anemia: molecular basis and clinical significance. Eur J Hum Genet 1997, 5: I 37- I48

31. Kruyt FA, Waisfisz Q, Dijkmans LM, Hermsen MA, Youssoufian H, Arwert $\mathrm{F}$, Joenje $\mathrm{H}$ : Cytoplasmic localization of a functionally active Fanconi anemia group A-green fluorescent protein chimera in human 293 cells. Blood 1997, 90:3288-3295

32. Joenje $H$, Lo ten Foe JR, Oostra $A B$, van Berkel CG, Rooimans MA, Schroeder-Kurth T, Wegner RD, Gille JJ, Buchwald M, Arwert F: Classification of Fanconi anemia patients by complementation analysis: evidence for a fifth genetic subtype. Blood 1995, 86:2156-2160
33. Ishida R, Buchwald M: Susceptibility of Fanconi's anemia lymphoblasts to DNA-cross-linking and alkylating agents. Cancer Res 1982, 42:4000-4006

34. Waisfisz $Q$, de Winter JP, Kruyt FA, de Groot J, van der Weel L, Dijkmans LM, Zhi Y, Arwert F, Scheper RJ, Youssoufian H, et al: A physical complex of the Fanconi anemia proteins FANCG/ XRCC9 and FANCA. Proc Natl Acad Sci U S A 1999, 96:10320. 10325

35. Burczynski ME, McMillian M, Ciervo J, Li L, Parker JB, Dunn RT 2nd, Hicken S, Farr S, Johnson MD: Toxicogenomics-based discrimination of toxic mechanism in HepG2 human hepatoma cells. Toxicol Sci 2000, 58:399-4I5

36. Huang Q, Dunn RT 2nd, Jayadev S, DiSorbo O, Pack FD, Farr SB, Stoll $\mathrm{RE}$, Blanchard KT: Assessment of cisplatin-induced nephrotoxicity by microarray technology. Toxicol Sci 200I, 63:196-207

37. Taylor WR, Stark GR: Regulation of the G2/M transition by $\mathbf{p 5 3}$. Oncogene 200I, 20:1803-1815

38. Barlow C, Hirotsune S, Paylor R, Liyanage M, Eckhaus M, Collins F Shiloh Y, Crawley JN, Ried T, Tagle D, et al: Atm-deficient mice: a paradigm of ataxia telangiectasia. Cell |996, 86:|59-|7|

39. $\mathrm{Xu} Y$, Baltimore D: Dual roles of ATM in the cellular response to radiation and in cell growth control. Genes Dev 1996, 10:2401-2410

40. Weeda G, Donker I, de Wit J, Morreau H, Janssens R, Vissers CJ, Nigg $A$, van Steeg $H$, Bootsma D, Hoeijmakers JH: Disruption of mouse ERCCI results in a novel repair syndrome with growth failure, nuclear abnormalities and senescence. Curr Biol 1997, 7:427-439

41. Hakem R, de la Pompa JL, Sirard C, Mo R, Woo M, Hakem A, Wakeham A, Potter J, Reitmair A, Billia F, et al: The tumor suppressor gene $\mathrm{Brca} I$ is required for embryonic cellular proliferation in the mouse. Cell 1996, 85:1009-1023

42. Patel KJ, Yu VP, Lee H, Corcoran A, Thistlethwaite FC, Evans MJ, Colledge WH, Friedman LS, Ponder BA, Venkitaraman AR: Involvement of Brca2 in DNA repair. Mol Cell I998, I:347-357

\section{Pre-publication history}

The pre-publication history for this paper can be accessed here:

http://www.biomedcentral.com/1471-2326/2/5/prepub
Publish with BioMed Central and every scientist can read your work free of charge

"BioMed Central will be the most significant development for disseminating the results of biomedical research in our lifetime. "

Sir Paul Nurse, Cancer Research UK

Your research papers will be:

- available free of charge to the entire biomedical community

- peer reviewed and published immediately upon acceptance

- cited in PubMed and archived on PubMed Central

- yours - you keep the copyright

Submit your manuscript here:

http://www.biomedcentral.com/info/publishing_adv.asp
BioMedcentral 